\title{
New directions for reinforced concrete coastal structures
}

\author{
Steven Nolan ${ }^{1^{*}}$ D, Marco Rossini ${ }^{2}$, Chase Knight ${ }^{3}$ and Antonio Nanni ${ }^{2}$
}

\begin{abstract}
Within the last century, coastal structures for infrastructure applications have traditionally been constructed with timber, structural steel, and/or steel-reinforced/prestressed concrete. Given asset owners' desires for increased service-life; reduced maintenance, repair and rehabilitation; liability; resilience; and sustainability, it has become clear that traditional construction materials cannot reliably meet these challenges without periodic and costly intervention. Fiber-Reinforced Polymer (FRP) composites have been successfully utilized for durable bridge applications for several decades, demonstrating their ability to provide reduced maintenance costs, extend service life, and significantly increase design durability. This paper explores a representative sample of these applications, related specifically to internal reinforcement for concrete structures in both passive (RC) and pre-tensioned (PC) applications, and contrasts them with the time-dependent effect and cost of corrosion in transportation infrastructure. Recent development of authoritative design guidelines within the US and international engineering communities is summarized and a examples of RC/PC verses FRP-RC/PC presented to show the sustainable (economic and environmental) advantage of composite structures in the coastal environment.
\end{abstract}

Keywords: Concrete bridges, Corrosion-resistant, Durability, Fiber-reinforced polymer, FRP

\section{Introduction}

Within the last century, coastal structures for infrastructure applications have traditionally been constructed with timber, structural steel, and/or steel-reinforced/prestressed concrete. Given public infrastructure owners' desire for increased service-life [1-3]; reduced maintenance, repair and rehabilitation liability [4, 5]; resilience [6]; and sustainability [7], it has become self-evident that traditional construction materials cannot reliably meet all these challenges for long-life coastal structures without periodic and often costly intervention $([8,9] \mathrm{pp}$. $1-2)$. This observation is reinforced by the expanding gap between Operation and Maintenance expenditures, verses Capital investment for public infrastructure [10].

Traditional construction materials can provide improved service-life for reinforced concrete structures with appropriate combinations of supplemental

\footnotetext{
* Correspondence: Steven.Nolan@dot.state.fl.us

${ }^{1}$ Florida Department of Transportation - State Structures Design Office,

Tallahassee, FL, USA

Full list of author information is available at the end of the article
}

materials, barrier coatings, stress reduction, and thicker concrete covers, but it is recognized that these structures will still require corrective repairs or replacement to reach contemporary service-life expectations (75 to 150 years) without compromising safety. Additionally, many mitigation techniques have been developed to delay or even reverse chloride ion ingress and steel depassivation through electro-chemical rehabilitation [11-14], and cathodic protection [15-18], but at significant relative expense and risk when contemplating the design of new coastal structures.

In the context of bridges, the corrosion of decks in North America is mostly due to the use of de-icing chemicals with collateral corrosion damage to beam ends and supporting pier caps due to runoff from leaking expansion joints, however the most prolific corrosion deterioration for bridge substructures is due to exposure to seawater in coastal structures, as recently reiterated by [19] (p.62): "The most serious threat to bridges in Florida is the corrosion of steel reinforced concrete substructures in coastal regions". It is significant that this statement 
comes from a state transportation agency that has one of the lowest bridge deficiency ratings in the US at $2.1 \%$ [8], with the third highest state population and relatively young bridge inventory due to its rapidly growing population (and transportation infrastructure needs) since the 1950's.

An alternative and perhaps more rational solution for reinforced concrete is to drastically minimize or remove the risk of corrosion, by adopting either highly corrosion-resistant (HCR) or non-corrosive reinforcing materials, respectively. Fiber-Reinforced Polymers (FRP) are non-corrosive material options for both reinforced concrete (RC) and prestressed concrete (PC) that utilizes decades old technologies but have yet to be fully integrated into the structural materials selection process. High nickel and chromium content stainless-steel (316 and 2205 alloys) are examples of HCR reinforcing materials that are gaining increased use for both new and rehabilitated structures. Aramid, basalt, carbon, and glass are example structural fibers that have been successfully utilized and increasing codified ([20-24]; ASTM 795717 [25];; CSA 806-19 [26-28];) for both RC and PC structural applications [29]. This paper focuses on the successful applications of FRP-RC \& PC, representing both structurally and economically reliable solutions.

\section{The inevitability of corrosion in coastal structures with traditional materials}

The time-dependent effect and cost of corrosion in transportation infrastructure is of extreme concern to owners of structures near the coastline. Repairs due to corrosion of reinforcing steel in concrete is estimated to be the most expensive repairs performed on coastal structures [19, 30, 31]. Chlorides accumulate on the concrete surface either through direct contact with the surrounding waterbody, by contaminated runoff flowing over the surface, or by exposure to salt-laden airborne spray. The presence and accumulation of chlorides at the surface drives ingress under a combination of complex transport processes, including absorption, convection, diffusion, migration, permeation, and thermodiffusion [32]. The chloride ingress process is further complicated by chloride binding, ionic interaction, aging factors, temperature, humidity, and submerged pressure effects [33-35]. Subsequent durability modelling is complicated by the presence of cracks in the concrete, the relative sustained or fatigue stress in the internal reinforcing, and reinforcing alloy and microstructure [36-38].

Under optimal conditions, the reinforcement in concrete remains in a passivated state stabilized by the high alkalinity of the concrete. However, when the chloride concentration exceeds a critical threshold at the reinforcement level, the passivation film is destabilized, and the initiation of localized corrosion occurs.
Furthermore, the process of carbonation reduces the concrete alkalinity and hinders passivation, accelerating corrosion in the presence of chlorides [39, 40]. Carbonation generally fosters corrosion over a larger surface of the reinforcement, whereas chloride induced corrosion can be very localized for high performance concrete, especially in the presence of cracks [41]. Recent studies on the coupling of carbonation and chloride induced corrosion has shown accelerated effects.

Corrosion degrades the reinforcement resulting in section loss and/or debonding with the surrounding concrete. The corrosion is further aggravated due to the formation of expansive oxidation products, producing cracks and splitting of the concrete to the surface, which then accelerates the access of chlorides. This increased chloride access eventually leads to delamination of the concrete cover and further loss of structural integrity. Chloride diffusion is accelerated, and corrosion initiation is more likely under carbonation than under only chloride ingress, likely in part due to carbonation releasing a certain portion of the bound chlorides into the pore solution (Zhu et al. [42, 43]). Much experimental work on chloride penetration and corrosion under a variety of conditions has been carried out, and, more recently, modeling approaches, including through artificial neural networks have shed light on this topic [44].

Several mitigation techniques including: 1) less permeable concrete formulations, primarily using supplemental pozzolans (e.g. granulated blast furnace slag, flyash, silica fume, metakaoline); 2) increased concrete cover; 3) topical or barrier treatments to seal the concrete surface (e.g. silanes, methyl methacrylate), are all recognized and currently used to reduce the penetration of chlorides in the concrete. However, these mitigation strategies only delay the onset of corrosion. Eventually, the chloride ions penetrate the cover concrete and accumulate to the critical concentration threshold which initiates corrosion of the internal steel rebars. Effective cathodic protection can be installed to delay or even prevent chloride ingress, but at additional expense, maintenance, and periodic replacement. Consideration of concrete cracking in corrosion durability models such as [45], fib Bulletin 34 [46], and [47], have been limited but recent research [48] highlights the accelerating effect, confirming anecdotal and documented observations of concrete structures in aggressive environments as identified by [19] p.62).

\section{Quantifying the corrosion liability of highway bridges \& structures}

The total annual cost of corrosion in the United State was reported as $\$ 276$ billion in 2002. In the world's second largest economy (China), the annual cost of corrosion was similarly estimated at $\$ 310$ billion [49]. It was 
further estimated that the annual direct cost for maintenance for concrete bridge decks due to corrosion of the reinforcement in the United States is around \$2 billion, and another $\$ 2$ billion spent for maintenance on concrete substructures due to the same reason [50]. Although the US national estimates are almost two decades old, the situation has not improved, with now almost $40 \%$ of US bridges over 50-years old [8], which was the typical design life expectation at the time of design. On a broader perspective, the 2016 IMPACT report [51] for similar applications, estimates a return on investment of 13 times expenditure for "corrosion prevention of rebar in concrete in critical facilities located in coastal environments".

\section{Response to an ever-growing challenge}

Current Federal Highway Administration (FHWA) and American Association of State Highway and Transportation Officials (AASHTO) funded efforts are primarily focused on preservation and quantification of the existing inventory of bridges to generate better predictive models and longer service life. The 2015 Fixing America's Surface Transportation (FAST) Act required that each State transportation agency develop a risk-based Transportation Asset Management Plan for all pavements and bridges on the National Highway System. The need to focus on asset preservation through proactive and targeted maintenance, repair, and rehabilitation (MR\&R) is indicatively reflected across other US public infrastructure sectors in a recent Congressional Budget Office report [10]. The graph in Fig. 1 was extracted from this report and shows a broadening gap between Operation and Maintenance costs verses Capital expenditure.

Given that for highway structures and bridges the operational costs are generally minimal, except for moveable bridges, most of this relative cost escalation can be attributed to an increasing maintenance burden. Whether the cost escalations are due to reactive or proactive maintenance, and what percentage can be attributed to the growing inventory size, is of little consequence to the focus and need identified in this paper for reducing the MR\&R burden. This strategy is also in direct alignment with the shared goal of the "ASCE Grand Challenge" to reduce infrastructure lifecycle costs by $50 \%$ by 2025 [4].

A leading example of this strategy is the Long-Term Bridge Performance (LTBP) program [5]. Some of the goals of the LTBP program to quantify and predictively model durability performance are poignantly relevant to this paper, including:

- Advance research in deterioration and predictive models.

- Apply cost analysis effectively.

- Support development of improved design methods and maintenance/bridge preservation practices.

- Quantify the effectiveness of various maintenance, repair, and rehabilitation strategies.

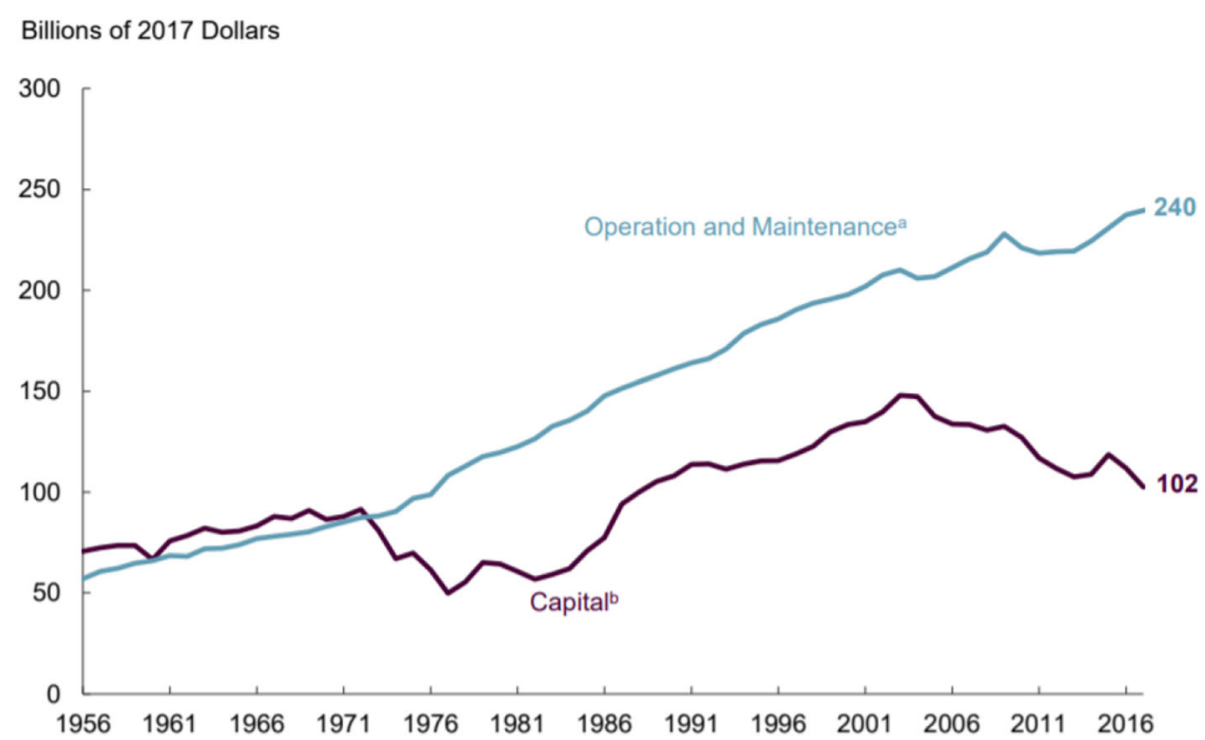

Fig. 1 State and Local Spending on Transportation and Water Infrastructure, by Category of Spending, 1956 to 2017 [10] p.16. a Dollar amounts are adjusted to remove the effects of inflation using price indexes for government spending that measure the prices of goods and services consumed by governments, including materials and other inputs used to operate and maintain transportation and water infrastructure. $\mathbf{b}$ Dollar amounts are adjusted to remove the effects of inflation using price indexes for government spending that measure the prices of materials and other inputs used to build transportation and water infrastructure 
This federal prioritization is understandable given accelerating replacement needs as "Interstate Era" bridges begin to collectively age well beyond their originally envisioned service-life. Without the injection of a major capitol works program, replacement of the deteriorating inventory is currently not possible with existing funding levels and revenue generation mechanisms.

There has been specific focus in the last decade on improving bridge construction durability through several FHWA "Every Day Counts" (EDC) program initiatives, including: Prefabricated Bridge Elements and Systems (PBES) [52]; Accelerated Bridge Construction [53]; Ultra-High Performance Concrete for Precast Connections [54]; and Ultra-High Performance Concrete for PBES [55]. Each of these EDC initiatives had goals beyond just accelerating construction and the associated safety and congestion reduction benefits, by intending to also improve durability through industrialized qualitycontrolled manufacturing of components and creating robust connection systems with reduced maintenance. Concrete cover thickness is sometimes allowed to be reduced under PBES, and AASHTO has allowed such practice for precast culvert structural elements for many years under their LRFD bridge design specifications, so consequently the additional quality of manufacturing may not always lead to increased durability, but only maintain the existing deemed-to-comply specification performance requirements.

\section{Under-utilized material technology and new tools}

While all these programs have primarily focused on improving quality and speed of construction, the class of durable Fiber-Reinforced Polymer (FRP) reinforcing has remained largely underutilized since the expiration of the Innovative Bridge Research and Construction (IBRC) funding program in 2005 [56]. This delayed attention to FRP is likely to change with FHWA's establishment of several regional University Transportation Centers (UTC) with their research priority of "Improving Durability and Extending the Life of Transportation Infrastructure" [57-60], and more recently, establishment of the National Center for Transportation Infrastructure Durability and Life-Extension UTC [61]. With a focus on durability and resilience, these UTCs hold strong promise through their collaboration efforts, for identifying scalable solutions that can economically extend the service life of our transportation infrastructure. Most recently, FHWA launched a new FRP Composites Technology website in April 2020 [62].

Recent development of authoritative design guidelines for both FRP-RC and FRP-PC in the US [26, 27] and Canada [28] complement and advance the existing repository of international design guidance [20-25].
Additionally, the second joint Strategic Highway Research Program [63] from 2007 to 2019, established a good foundation for future development of a ServiceLife Design bridge specification, recognizing the importance of durability in the holistic cost of transportation infrastructure. Although FRP was not explicitly considered in the development of the final "Guide Specification for the Service Life Design of Highway Bridges" [1], a framework has been established that could also integrate FRP structural materials under "Class D" reinforcement (highly corrosion-resistant materials).

\section{Drastic consequences demand different solutions}

There is little dispute regarding the need for corrosion mitigation solutions for existing structures while simultaneously researching improved solutions for new construction. However, there is a missed opportunity with existing FRP technology that could be broadly deployed immediately. There will likely never be sufficient funding to replace all the deficient infrastructure with new durable, resilient solutions. However, for those replacements that are feasible, it is considered by the authors a societal disservice to continue building strategic infrastructure using conventional legacy materials with proven inability to weather the challenge of highly corrosive environments. The most rational solution is to eliminate the possibilities of corrosion completely rather than delay it.

There has also been an underutilization of life-cycle cost (LCC) analysis for bridges and seawall structures in comparing the true cost of ownership. When LCC is utilized, the durability models are typically optimistic and biased against more expensive durable solution by: 1) ignoring the effects of cracking in concrete as previously discussed; 2) use of inflated discount rates (3 to 6\%) not reflective of public infrastructure investment; and 3) lack of recognition that the construction cost inflation index [64] is significantly higher than general inflation which is implicitly incorporated into published real discount rates such as [65]. In recent years OMB Circular No. A-94 Appendix $\mathrm{C}$ has published much lower recommended discount rates but these still suffer from the limitations identified above when applied to 75 or 100 year target service life.

FRP composites have been successfully utilized for durable reinforced and prestressed concrete bridge applications for more than 30 years, demonstrating their ability to provide reduced maintenance cost and extended service-life, due to significantly increased durability. The FHWA EDC and LTBP programs could significantly benefit from embracing FRP-RC/PC technologies for Highly Corrosion-Resistant (HCR-) solutions and thereby substantially improve the life-cycle cost and future asset management of owners' bridge inventories. 
Initial higher cost is often cited by owners and engineers for not specifying FRP composites in more applications, however these low usage volumes continue to contribute to higher cost thru a lack of industrial scaling and competition. Furthermore, a lack of demand from owners and engineers for higher mechanical performance properties and refinement of reliability margins of safety consistent with conventional materials, ensures that less competitive designs propagate.

A collaborative proposal from composites industry representatives, Transportation Research Board Committee AFF80, and AASHTO subcommittee T-6 (FRP Composites), under the EDC-5 solicitation process was unsuccessful in 2018 [66]. Some of the collective concerns from reviewers included: "How do we inspect, load rate, maintain, repair, and confidently determine remaining service life", for these types of bridge structures or components? Many of these concerns may be resolved under future research, such as the recent FHWA Broad Agency Announcement 693JJ321BAA0001, Topic 10: HIBS10-FRP-001 (Safety Inspection and Evaluation of Bridges with FRP Composites). While these are important questions to be more fully researched and refined, 30-years of experience from existing FRP-RC/PC infrastructure and the lack of comprehensive cost-effective solutions with conventional materials, should be sufficient motivation to proceed with broader adoption as Florida Department of Transportation (FDOT) and a few other leading state transportation agencies are doing [67].

\section{Structure type and components most benefiting from FRPRC-solutions \\ Composition}

FRP reinforcement is made from continuous fibers, typically glass (GFRP), basalt (BFRP), carbon (CFRP), or aramid (AFRP). Fibers are impregnated with polymeric resin, typically thermoset vinyl ester, epoxy, or polyester. Thermoplastic resins have also shown promising performance, and of specific interest for post-processing formability and recyclability [68]. Fibers provide the tensile strength and stiffness, and the resin acts as a binder providing load transfer to the adjacent fibers. The role of an FRP reinforcement manufacturer is to combine fibers and resin into pultruded composite bars. During pultrusion, fibers are coated with resin and drawn through a heated die from which they emerge as a semi-final product. Then, various surface preparation techniques can be employed to enhance the bond of the FRP bar to the concrete, including sand coating, surface deformation, helical grooving, or combinations of these methods. Other manufacturing techniques include combining a number of small-diameter composite bars which can be twisted into a single strand providing a flexible configuration (similar to steel 7-wire strand) which can be coiled for shipping and handling, allowing for long precast pre-tensioned and post-tensioned concrete applications $[69,70]$. Being a non-ferrous material, FRP is non-corrosive and impervious to chloride attack.

\section{Applications}

Given these attributes and recognition that corrosion is a significant challenge for much of the built environment, this paper attempts to address a small, but highrisk subset of transportation infrastructure predominantly within the splash zone as defined in AASHTO [1]. The risk of chloride penetration and migration through concrete is typically higher for components of coastal $\mathrm{RC}$ structures in direct contact with, or in close proximity to seawater. In these locations as previously highlighted, the propensity for chloride build-up at the concrete surface results in higher concentration gradients, which are favorable for diffusion. In addition, chlorides can rapidly penetrate the concrete if cracks are present. Following are examples of such components that would benefit the most from the use of CRsolutions, beyond bridge decks which have been adequately covered by others as referenced in the Validation Examples section.

\section{Seawalls}

$\mathrm{RC}$ seawalls typically consist of precast wall panels, castin-place bulkheads, and tie-back systems when needed. Seawall elements located in the splash zone commonly require premature repairs or replacement due to severe damage caused by the corrosion of carbon-steel reinforcement. Use of steel sheet pile walls is typically discouraged for long-term coastal applications due to the extensive thru-thickness section loss, perforation and blistering of protective coatings that occurs in the splash zone [71, 72]. Seawalls are utilized extensively along or near coastal areas for bridge infrastructure as well as protection of coastal commercial and residential properties [73]. Figures 2 and 3 show typical examples of severe corrosion damage that can be avoided using CRsolutions.

\section{Bridge foundations}

Bridge foundation elements in the splash zone are also subject to high corrosion risk, even when designed with considerations for environmental exposure. With carbon-steel reinforcement, additional life-cycle costs are incurred not only by the necessity of initial protection strategies (enhanced concrete mix design and concrete cover thickness), but also the mitigation of corrosion damage on existing elements. In most cases and within limitations, appropriately designed cathodic protection (CP) systems can extend the life of piles, 
(a)

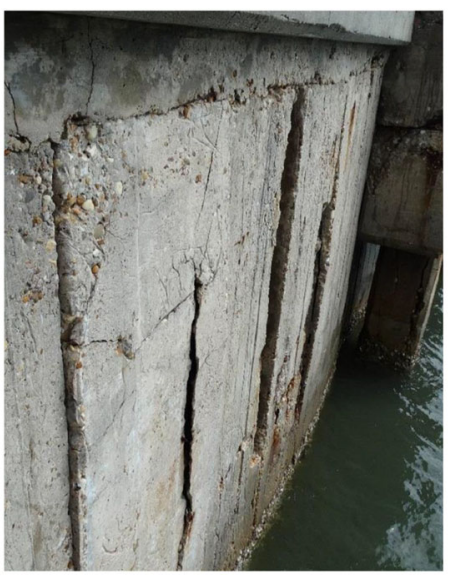

(b)

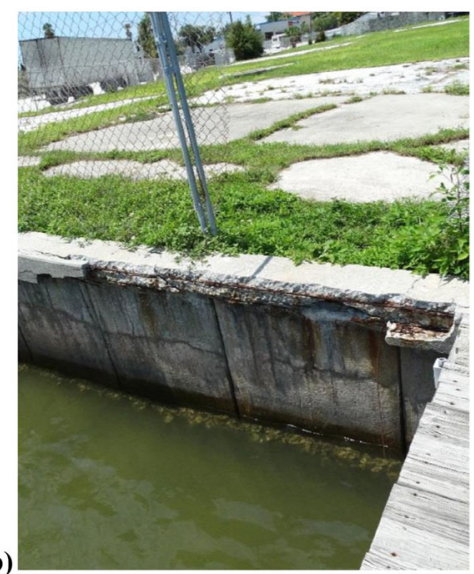

Fig. 2 Typical examples of severe corrosion damage on concrete seawalls [95]

footings, columns, etc. with corrosion damage until complete replacement is required. However, CP systems incur significant costs for monitoring and maintenance to be effective. The design of bridge foundations with CR-solutions would eliminate the need and cost of additional corrosion prevention and mitigation strategies.

\section{Low-level superstructures}

The superstructure components of bridges (decks or slabs, girders, and traffic railings) over waterways with high chloride concentrations, are desirably elevated above the splash zone as much as possible. Where provision of higher member elevations is not physically or economically feasible, steel-RC has proven to be very susceptible to corrosion damage. Moreover, corrosion mitigation strategies such as cathodic protection can be very complicated, and often improbable, for such elements due to the complex layout of reinforcing steel. Therefore, CR-solutions for these elements are more reliable for achieving desirable structural longevity of lowelevation superstructure elements.

\section{Validation examples}

Several examples are presented with supporting archival literature references showing the viability and suitability of FRP composite structures in the coastal environment. The first six projects are the earliest known examples of FRP-RC or PC bridge component construction, while the last three bridges highlight more recent examples for entire bridges utilizing predominantly FRP reinforcing and/or prestressed concrete. It has been reported that more than 270 bridges have been completed using FRP reinforcement in the US and Canada [74], and more than 23 of these include CFRP prestressing in the US [75].

\section{Ulenbergstrasse bridge, Düsseldorf, Germany 1986 (GFRP- $\mathrm{PC})$}

The world's first vehicular bridge using FRP E-glass tendons with polyester resin and polyamide coating for protection against chemical and mechanical attack [76]. (a)

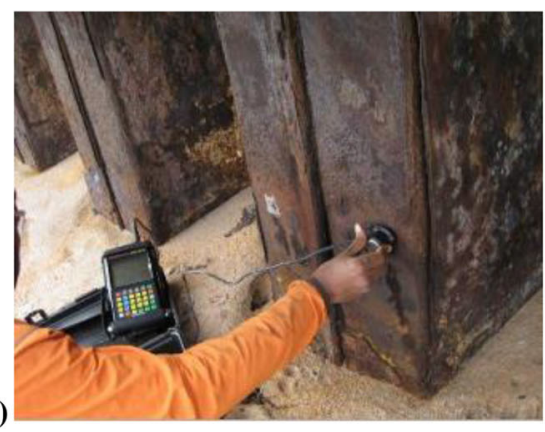

(b)

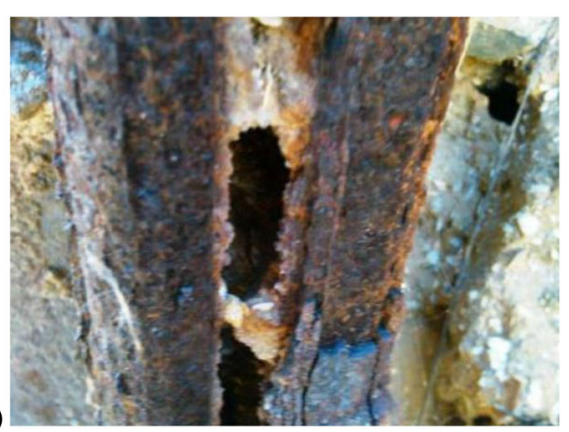

Fig. 3 Typical examples of severe corrosion damage on steel sheetpile seawalls [71]: a Section thickness testing; b Perforation at joint 


\section{Shinmiya bridge, Japan 1988 (CFCC-PC)}

The world's first Carbon Fiber Composite Cable (CFCC) prestressed concrete bridge located adjacent to the Sea of Japan. This bridge was constructed as a replacement for a 21-year old prestressed concrete bridge suffering severe corrosion deterioration. Additional prestressed beams were set adjacent to the structure for in-place weathering and then tested to destruction in 1994 and 2017. The flexural strengths exceeded the original beams by $20 \%-25 \%$, possibly due to concrete strength gain and the compression-controlled failure mode [77].

\section{Beddington Trail bridge, Calgary, Alberta 1993 (CFCC \& (FRP-PC)}

The first highway bridge in North American with FRP prestressing. This is a two-span skewed bridge using CFCC (helically twisted) tendons and Leadline (straight single) strands for precast/pretensioned bulb-T girders [70]. Three girder lines contained CFCC and three CFRP Leadline strands to match the remaining conventional prestressed girders.

\section{Hall's Harbor Wharf, bay of Fundy, Nova Scotia 1999 (GFRP-RC)}

The Hall's Harbor Wharf was the first marine structure in Canada to be built using Intelligent Sensing for Innovative Structures (ISIS Canada) technology and design concepts [78]. The wharf, located on the Bay of Fundy shore in Nova Scotia, comprises steel-free precast concrete panels with GFRP bars and concrete pile cap beams reinforced with a hybrid GFRP-steel bar system.

\section{McKinleyville bridge, West Virginia, 1998 (GFRP-RC)}

McKinleyville Bridge was one of the first bridge decks to use GFRP rebar in the US. GFRP bars were extracted from the bridge after 15 years of service life, showing good durability performance [79]. Other bridges that followed include Gills Creek Bridge, O'Fallon Park Bridge, Salem Ave Bridge, Bettendorf Bridge, Cuyahoga County Bridge, Sierrita de la Cruz, Thayer Road Bridge, Bourbon County Bridge. The ACI Strategic Development Council sponsored a durability review of the GFRP bars in 11 of these early bridges to assess the performance after 15 to 20-year of service life [80]. Similar to earlier studies on Canadian bridges [81-83], the standard ASTM accelerated aging tests were found to be very conservative when compared to in-service performance strength testing.

\section{Val-Alain bridge, Quebec 2004 (GFRP-RC)}

Val-Alain Bridge was the first completely steel-free deck in Canada. In 2015, concrete cores were taken, and the encapsulated GFRP bars were evaluated to assess durability [84]. Other early Canadian bridges with partial
GFRP reinforcing replacement include Joffre Bridge [85], Chathman Bridge [86], Crowchild Trail Bridge [87], and Waterloo Creek Bridge [88]. Additional long-term durability investigations are also documented for the 3rd Concession Rd. Bridge over Highway 401 [89, 90].

\section{Innovation Bridge, Coral Gables, FL 2016 (GFRP-RC, BFRP- RC \& CFRP-PC)}

Located on the University of Miami campus in Coral Gables (FL) the Innovation Bridge is a $65-\mathrm{ft}$. long single span PC bridge. The bridge serves as a pedestrian passageway and comprises a variety of non-corrosive reinforcement solutions including CFRP prestressing strands, GFRP bars, and the first deployment of BFRP closed stirrups and preassembled reinforcement cages in bridges. The structure is an entirely steel-free structure designed for resilience and durability in aggressive subtropical exposure $[91,92]$.

Halls River bridge, Homosassa, FL 2019 (GFRP-RC \& CFRPPC)

Halls River Bridge is a five-span vehicular bridge constructed between 2016 and 2019, using entirely CRsolutions and mostly FRP reinforcement. The structure includes CFRP-PC bearing piles, CFRP-PC/ GFRP-RC sheet piles, hybrid Carbon-Steel-PC/GFRPRC sheet piles, GFRP-RC pile bent caps and bulkhead caps, Hybrid Composite Beams with a GFRP-RC bridge deck, GFRP-RC traffic railings, GFRP-RC approach slabs, and a GFRP-RC gravity wall. The unprecedented variety and completeness of the material and structural solutions deployed make the Halls River Bridge a valuable source for data. Monitoring protocols were implemented at the design and construction stages and will be continued through the early service life of the structure [93]. A Life-Cycle Cost analysis was later performed by $[30,31]$, proving a complete FRP-RC/PC design to be the least impacting solution from both an economic and environmental perspective over an estimated service life of 100years.

Innovation Dock, Coral Gables, FL 2019 (GFRP-RC \& BFRP$\mathrm{RC})$

The Innovation Dock (iDock) is a full replacement of a marine boat dock damaged by hurricane Irma. The new structure used PC members partially mixed with seawater and reinforced with GFRP and BFRP bars [94] and pioneered the deployment of Accelerated Bridge Construction (ABC) methods using Prefabricated Bridge Elements and Systems (PBES) for coastal structures. 
NE 23rd avenue over lbis waterway, City of lighthouse point, FL 2020 (GFRP-RC/PC \& CFRP-PC)

The NE 23rd Ave. bridge is the first GFRP-RC threespan continuous flat-slab vehicular bridge in the US. The abutments also include the first soldier-pile bulkhead-seawall with GFRP-RC precast panels, two demonstration 18-in. square GFRP-PC piles in the wing walls, and combined CFRP-PC bearing/soldier-piles for the end bents. The bridge includes GFRP-RC for cast-inplace end bents, intermediate bent caps, and bulkhead caps. Early construction activities demonstrated swagecoupling [95] and partial prestressing [70] of GFRP bars that were coiled during shipping to the precast yard, for fabrication of two seawall soldier-piles (Fig. 4a \& b). Construction of the bulkhead-seawall was completed in December 2020, and the bridge is expected to be completed by early 2021 .

\section{US-41 northbound over North Creek, osprey, FL 2020 (GFRP-RC)}

The US-41 (Florida State Road 5) bridge is the first GFRP-RC two-span continuous flat-slab highway bridge in the US. It is the second soldier-pile bulkhead-seawall in Florida with GFRP-RC precast panels, but utilizes larger 24-in. square CR-prestressed piles compared to 23rd Ave. NE. For this project, the piling precaster/contractor choose to utilize 2205 duplex alloy stainless-steel prestressing strands (ASTM [96]) in lieu of the CFRP option, as permitted per FDOT's Standard Specification [97], but only when highly reaction pozzolans are added to the concrete mix. The bridge includes a GFRP-RC cast-in-place superstructure (Fig. 4c), traffic railings, and bulkhead seawall caps. Construction is expected to be completed by early 2021 [98].

\section{Cost comparisons for FRP-RC solutions}

There is a paucity of rigorous cost comparisons between conventional structural materials versus FRP-RC and PC solutions. Furthermore, academic or industry consensus on methodologies, unit rates, maintenance costs, frequency, escalation, and risk factors need to be established for reliable comparisons. The relative benefits of sustainability and adaption strategies against future environmental risks are also yet to be reliably established. Recent published studies that support long-term economical and/or environmental preferences for FRP-RC/ PC solutions above HCR or conventional designs utilize Life-Cycle Cost (LCC) analysis and Life Cycle Assessment (LCA), respectively.

Younis et al. [99] performed LCC analysis to verify the cost savings associated with GFRP reinforced using environmentally friendly structural concrete incorporating seawater and recycled coarse aggregates, and GFRP reinforcement. The design alternatives were compared for a conceptual high-rise building, using conventional concrete with carbon-steel reinforcement, against seawater-mixed, recycled-aggregate, GFRP-reinforced concrete. Younis et al. [100] also compared the longterm cost performance among four reinforcing materials: conventional carbon-steel; epoxy-coated carbon-steel; stainless-steels; and GFRP reinforcing, for a concrete water chlorination tank. Both studies had preferential outcomes for the GFRP reinforced alternative.

Cadenazzi et al. [30, 31] performed LCC analysis and LCA on the Halls River Bridge using conceptual alternative designs with both conventional and HCR materials. The findings implied that the FRP-RC/PC solutions where typically preferential. The LCC analysis preferential solution was somewhat dependent on the choice of the discount rate which attempts to address inflation and the cost of capital financing. Cadenazzi et al. [101] expanded on the LCC analysis with a probabilistic approach in an attempt improve risk evaluation for many of the LCC variables (discount rate, reconstruction cost, maintenance timing, frequency, and cost). Similarly, probabilistic analysis of the rates of corrosion and (a)

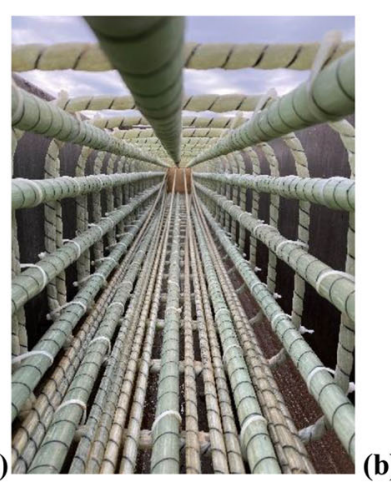

(b)

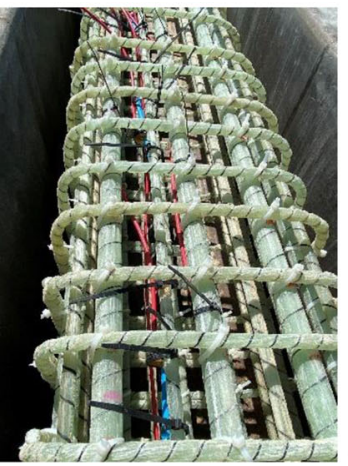

(c)

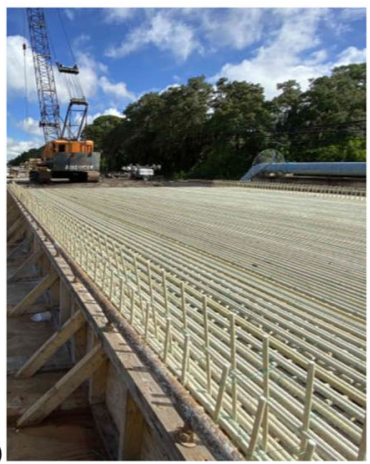

Fig. 4 Typical examples of new GFRP-RC/PC construction: a Soldier pile fabrication before tensioning, and $\mathbf{b}$ after tensioning \#4 bar strands [68]; $\mathbf{c}$ CIP flat-slab bridge conservative reinforcing layout 
structural effects [102] may help to refine the reliability (timing and frequency) of corrosion mitigation intervention estimation for conventional materials in future studies. The LCA looked at five impact categories (Ozone Depletion Potential, Global Warming Potential, Photochemical Oxidant Creation Potential, Acidification Potential, and Eutrophication Potential) with Global Warming and Eutrophication impacts favoring FRP-RC/ PC solutions, and SS-RC/PC (HCR) for the other impacts under the cradle-to-grave scenario. Additional comparative studies in both LCC and LCA should be pursued under differing environmental conditions and scale, to provide designers and owners with better decision-making tools.

\section{Conclusion}

Over more than 30 years of field applications in bridge structures, FRP reinforcement has proved to be a reliable and durable material, able to fulfill the owners' demand for increased service-life, reduced maintenance costs, resilience, and sustainability. Considering that almost 300 bridges have been completed using FRP reinforcement and prestressing in the US and Canada, there is substantial validation available for the structural engineering community. Embracing this cost-effective solution would avoid much of the ever-present risk of corrosion and future preservation efforts that are currently needed for coastal bridges and similarly exposed infrastructure. Additional comparative studies on contemporary structures using both LCC and LCA are important for holistically identifying the optimal economic and environmental solutions for sustainable designs.

\footnotetext{
Abbreviations

AASHTO : American Association of State Highway and Transportation Officials; ACMA: American Composite Manufacturers Association; ASCE: American Society of Civil Engineers; BFRP: Carbon Fiber-Reinforced Polymer; CBO: Congressional Budget Office; CSA: Canadian Standards Association; CFCC: Carbon Fiber Composite Cable; CFRP: Carbon FiberReinforced Polymer; CP: Cathodic Protection; CR-: Corrosion-Resistant; EDC: Every Day Counts (FHWA); FDOT: Florida Department of Transportation; FHWA: Federal Highway Administration; fib: Fédération Internationale du Béton; FRP: Fiber-Reinforced Polymer; GFRP: Glass Fiber-Reinforced Polymer; GOST: Governmental Standards (Russian Federation); IBRC: Innovative Bridge Research and Construction; LTBP: Long-Term Bridge Preservation; MR\&R: Maintenance, Repair and Rehabilitation; NASEM: National Academies of Science, Engineering, and Medicine; PBES: Prefabricated Bridge Elements and Systems; PC: Prestressed Concrete; RC: Reinforced Concrete;

UTC: University Transportation Centers
}

\section{Acknowledgements}

The second and fourth authors gratefully acknowledge the financial support from "Sustainable concrete using seawater, salt-contaminated aggregates, and non-corrosive reinforcement" Infravation, 31109806.005-SEACON. The opinions, findings and conclusions expressed in this publication are those of the author(s) and not necessarily those of the Florida Department of Transportation or the U.S. Department of Transportation.

\section{Authors' contributions}

SN conceived the manuscript, provided the outline, collected historical content, quantification of corrosion effects, and presented an abbreviate version at the 2019 Bridge Engineering Institute Conference. CK contributed to the corrosion and mitigation, and seawall content and photos. MR and AN contributed the contemporary validation example projects and the McKinleyville Bridge/ACI-SDC investigations. All authors were involved in editorial review of the final paper. The author(s) read and approved the final manuscript.

\section{Funding}

The second and fourth authors gratefully acknowledge the financial support during the Halls River Bridge demonstrator project, from "Sustainable concrete using seawater, salt-contaminated aggregates, and non-corrosive reinforcement" Infravation, 31109806.005-SEACON.

Availability of data and materials

Data sharing is not applicable to this article as no datasets were generated or analyzed during the current study.

\section{Competing interests}

The authors declare that they have no competing interests.

\section{Author details}

${ }^{1}$ Florida Department of Transportation - State Structures Design Office, Tallahassee, FL, USA. 'University of Miami - College of Engineering, Coral Gables, FL, USA. ${ }^{3}$ Florida Department of Transportation - State Materials Office, Gainesville, FL, USA.

Received: 28 July 2020 Accepted: 4 January 2021

Published online: 01 February 2021

\section{References}

1. AASHTO (2020) Guide specification for the service life Design of Highway Bridges. American Association of State Highway and Transportation Officials, Washington, DC

2. Shayan A, Xu A (2016) "Realising 100-year bridge design life in an aggressive environment: review of the literature", technical report no. In: AP-T313-16, November 2016. Austroads Ltd., Sydney

3. NASEM (2013) Design guide for bridges for service life. National Academies of Sciences, Engineering, and Medicine, Washington, DC: The National Academies Press. https://doi.org/10.17226/22617

4. ASCE (2015) ASCE Grand Challenge. American Society of Civil Engineers, Reston https://www.asce.org/grand-challenge/

5. FHWA (2019a) LTBP InfoBridge. In: Long Term Infrastructure Performance Programs. Federal Highway Administration, Washington, DC https:// highways.dot.gov/research/research-programs/infrastructure/long-terminfrastructure-performance

6. FHWA (2019b) Building resilient transportation. Federal Highway Administration, Washington https://www.fhwa.dot.gov/environment/ sustainability/resilience/publications/bcrt_brochure.cfm

7. FHWA (2019c) Sustainable highways initiative. Federal Highway Administration, Washington, DC https://www.sustainablehighways.dot.gov/

8. ASCE (2017) 2017 infrastructure report card - bridges. American Society of Civil Engineers, Reston https://www.infrastructurereportcard.org/cat-item/ bridges/

9. Reitsema AD, Lukovi'c M, Grünewald S, Hordijk DA (2020) Future infrastructural replacement through the smart bridge concept. Materials 13: 405. https://doi.org/10.3390/ma13020405

10. CBO (2018) US Public Spending on Transportation and Water Infrastructure 1959 to 2017, Publication No. 54539. Congressional Budget Office, Washington, DC, p 16 https://www.cbo.gov/publication/54539

11. Liu Y, Shi X (2009) Electrochemical chloride extraction and electrochemical injection of corrosion inhibitor in concrete: state of the knowledge. Corros Rev 27(1-2):53-82

12. Liu $Y$, Shi $X$ (2012) lonic transport in cementitious materials under an externally applied electric field: finite element modeling. Constr Build Mater 27:450-460

13. Mao LX, Hu Z, Xia J, Feng G, Azim I, Yang J, Liu Q (2019) Multi-phase modelling of electrochemical rehabilitation for ASR and chloride affected concrete composites. Compos Struct 207:176-189. https://doi.org/10.1016/j. compstruct.2018.09.063 
14. Yeih W, Chang JJ, Chang CC, Chena KL, Chib MC (2016) Electrochemical chloride removal for reinforced concrete with steel rebar cage using auxiliary electrodes. Cem Concr Compos 74:136-146

15. Connal, J., Berndt, M. 2009. "Sustainable bridges - 300 year design life for second gateway bridge", Austroads bridge conference, 7th, 2009, Auckland, NZ

16. Hartt W, Chu W (2009) Utility of Submerged Anodes for Cathodic Protection of Above-Waterline Reinforced Concrete Elements-Part 1: Bulk Zinc Anodes. Corrosion 65(8):545-558

17. Kessler RJ, Powers RG (1991) Use of marine substructure cathodic protection systems in Florida, past and present. Transportation Research Board Annual Meeting, 1991, Washington, DC

18. Kessler RJ, Powers RG, Lasa IR (1999) History and performance of marine substructure Cathodic protection Systems in Florida. In: Proceedings International Conference on Corrosion and Rehabilitation of Reinforced Concrete Structures, held December 7-11, 1998, Orlando, FL. U.S. Department of Transportation/Federal Highway Administration, Washington, DC

19. Clarke J (2020) Bridge inventory 2020 annual report. Florida Department of Transportation, Tallahassee, p 62 https://www.fdot.gov/maintenance/ bridgeinfo.shtm

20. $\mathrm{ACl}$ (2004) ACl 440.4R-04(11) Prestressing concrete structures with FRP tendons (reapproved 2011). American Concrete Institute, Farmington Hills

21. $\mathrm{ACl}$ (2015) $\mathrm{ACl} 440.1 \mathrm{R}-15$ guide for the design and construction of structural concrete reinforced with fiber-reinforced polymer (FRP) bars. American Concrete Institute, Farmington Hills

22. fib (2007) FRP Reinforcement in RC Structures, Bulletin No. 40. International Federation for Structural Concrete, Lausanne. https://doi.org/10.35789/fib. BULL.0040

23. GOST (2012) Fibre-reinforced polymer Bar for concrete reinforcement, General specifications GOST 31938-2012. Interstandard, Russia

24. JSCE (1998) Recommendation for design and construction of concrete structures using continuous Fiber reinforcing materials. Japan Society of Civil Engineer, Tokyo

25. Minstroy (2017) Concrete structures reinforced with fibre-reinforced polymer reinforcing bars. Design rules. Ministry of Construction, Housing and Utilities of the Russian Federation, Moscow, SP 295.1325800.2017

26. AASHTO (2018a) AASHTO LRFD bridge design guide specifications for GFRPreinforced concrete, 2nd edn. American Association of State Highway and Transportation Officials, Washington, DC

27. AASHTO (2018b) AASHTO guide specifications for the Design of Concrete Bridge Beams Prestressed with CFRP systems, 1st edn. American Association of State Highway and Transportation Officials, Washington, DC

28. CSA (2017) Design and construction of building structures with fibrereinforced polymers S806-12 (R2017). Canadian Standards Association (CSA), Mississauga

29. ACl. 2021. "Field applications of non-conventional reinforcing and strengthening methods for bridges and structures", SP-346. (In press)

30. Cadenazzi T, Dotelli G, Rossini M, Nolan S, Nanni A (2019a) Life-cycle cost and life-cycle assessment analysis at the design stage of a fiber-reinforced polymer-reinforced concrete bridge in Florida. Adv Civil Eng Mater 8(2). https://doi.org/10.1520/ACEM20180113

31. Cadenazzi T, Dotelli G, Rossini M, Nolan S, Nanni A (2019b) Cost and environmental analyses of reinforcement alternatives for a concrete bridge. Struct Infrastruct Eng 16. https://doi.org/10.1080/15732479.2019.1662066

32. Nguyen PT, Bastidas-Arteaga E, Amiri O, El Soueidy C (2017) An efficient chloride ingress model for long-term lifetime assessment of reinforced concrete structures under realistic climate and exposure conditions. Int J Concr Struct Mater 11:199-213. https://doi.org/10.1007/s40069-017-0185-8

33. Bastidas-Arteaga $E$, Chateauneuf A, Sánchez-Silva M, Bressolette P, Schoefs F (2011) A comprehensive probabilistic model of chloride ingress in unsaturated concrete. Eng Struct 33(3):720-730. https://doi.org/10.1016/j. engstruct.2010.11.008

34. Martin-Perez B, Zibara H, Hooton RD, Thomas MDA (2000) A study of the effect of chloride binding on service life predictions. Cem Concr Res 30:1215-1223

35. Zenunovic D, Residbegovis N, Folic R (2017) Chloride penetration through concrete cover under pressure. In: Proceedings of the 1st International Conference on Construction Materials for Sustainable Future, Zadar. University of Zagreb, Zagreb, pp 19-21. ISBN: 978-953-8168-04-8

36. Wang XY, Zhang LN (2016) Simulation of chloride diffusion in cracked concrete with different crack patterns. Adv Mater Sci Eng 2016(Article ID 1075452):11. https://doi.org/10.1155/2016/1075452
37. Wu J, Diao B, Cao Y, Zhong J, Shi X (2020) Chloride concentration distributions in fatigue damaged $\mathrm{RC}$ beams revealed by energy-dispersive X-ray spectroscopy. Construction Building Mater 234:117396. https://doi.org/ 10.1016/j.conbuildmat.2019.117396

38. Zhao Q, Lu L (2019) Durability of subsea tunnels under the coupled action of stress and chloride ions. Appl. Sci 9(10):1984. https://doi.org/10.3390/ app9101984f

39. Malheiro R, Camões A, Meira G, Amorim MT, Castro-Gomes J (2020) Interaction of carbonation and chloride ions ingress in concrete. RILEM Tech Lett 5:56-62. https://doi.org/10.21809/rilemtechlett.2020.126

40. Šomodíková M, Strauss A, Zambon I (2020) fib models for modeling of chloride ion ingress and concrete carbonation: levels of assessment of input parameters. Struct Concrete 2020:1-8. https://doi.org/10.1002/suco.201900401

41. Poursaee A, Hansson CM (2008) The influence of longitudinal cracks on the corrosion protection afforded reinforcing steel in high performance concrete. Cem Concr Res 38:1098-1105

42. Shen $\mathrm{XH}$, Jiang WQ, Hou D et al (2019) Numerical study of carbonation and its effect on chloride binding in concrete. Cem Concr Compos 104(2019):103402

43. Zhu X, Zi G, Lee W, Kim, S, Kong J (2016) Probabilistic analysis of reinforcement corrosion due to the combined action of carbonation and chloride ingress in concrete. Construct Build Mat 124:667-680. https://doi. org/10.1016/j.conbuildmat.2016.07.120

44. Liu Q, labal MF, Yang J, Lu X, Zhang P, Rauf M (2021) Prediction of chloride diffusivity in concrete using artificial neural network: modelling and performance evaluation. Constr Build Mater 266:121082

45. Duracrete (2000) Probabilistic performance based durability design of concrete structures. In: The European Union-Brite EuRam III, BE95-1347/R17, CUR, Gouda, The Netherlands

46. fib (2006) Model Code for Service Life Design, fib Bulletin 34, February 2006. International Federation for Structural Concrete, Lausanne. https://doi.org/ 10.35789/fib.BULL.0034

47. Life-365 (2012) Service life prediction model and computer program for predicting the service life and life-cycle cost of reinforced concrete exposed to chlorides. In: Life 365 Consortium II, January 2012, p 80

48. Jung S, Ryu H, Karthick S, Kwon S (2018) Time and crack effect on chloride diffusion for concrete with Fly ash. Int J Concr Struct Mater 12:14. https:// doi.org/10.1186/s40069-018-0230-2

49. Hou B, Li X, Ma X, Du C, Zhang D, Zheng M, Xu W, Lu D, Ma F (2017) The cost of corrosion in China. npj Mater Degrad 1:4. https://doi.org/10.1038/ s41529-017-0005-2

50. FHWA (2002) Corrosion costs and preventive strategies in the United States", Publication no -RD-01-156. Federal Highway Administration turnerFairbank highway research center, McLean

51. Koch G, Varney J, Thompson N, Moghissi O, Gould M, Payer J (2016) International measures of prevention, application, and economics of construction technologies study. NACE International, Houston

52. FHWA (2011) EDC-1 Initiative: Prefabricated Bridge Elements and Systems (PBES). In: Every Day Counts program, 2011-2012. Federal Highway Administration Turner-Fairbank Highway Research Center, McLean

53. FHWA (2013) EDC-2 Initiative: Accelerated Bridge Construction (ABC). In: Every Day Counts program, 2013-2014. Federal Highway Administration Turner-Fairbank Highway Research Center, McLean

54. FHWA (2015) EDC-3 Initiative: Ultra-High Performance Concrete Connections for Prefabricated Bridge Elements (UHPC). In: Every Day Counts program, 2015-2016. Federal Highway Administration Turner-Fairbank Highway Research Center, McLean

55. FHWA (2017) EDC-4 Initiative: Ultra-High Performance Concrete Connections for PBES. In: Every Day Counts program, 2017-2018. Federal Highway Administration Turner-Fairbank Highway Research Center, McLean

56. NASEM (2019) Performance of bridges that received funding under the innovative bridge research and construction program. National Academies of Sciences, Engineering, and Medicine, Washington, DC: The National Academies Press. https://doi.org/10.17226/25358

57. CAIT (2018) "Center for Advanced Infrastructure and Transportation" region 2 university transportation center. Rutgers, Piscataway http://cait.rutgers.edu/

58. CIAMTIS (2018) "Center for Integrated Asset Management for multi-modal transportation infrastructure systems" region 3 university transportation center. Pennsylvania State University, University Park http://r3utc.psu.edu/

59. TIDC (2018) Transportation infrastructure durability center. Region 1 university transportation center, University of Maine, Orono http://www.tidcutc.org/ 
60. TRANSET. 2018. "Transportation consortium of Southcentral states", Region 6 university transportation center, Louisiana State University. http://transet.Isu. edu/

61. TriDurLE (2019) National Center for durability and life extension of infrastructure. Washington State University, Pullman https://ridurle.wsu.edu/

62. FHWA (2020a) Fiber reinforced polymer (FRP) composites technology. Federal Highway Administration, Office of Bridges and Structures, Washington, DC (Accessed 2 Apr 2020) https://www.fhwa.dot.gov/bridge/ composite/

63. SHRP2. 2007-2019. "Second Strategic Highway Research Program" Renewal Program, American Association of State Highway and Transportation Officials, Washington, DC

64. FHWA (2020b) National Highway Construction Cost Index. Federal Highway Administration, Office of Policy and Government Affairs \& Office of Transportation Policy Studies, Washington, DC (Accessed 1 Oct 2020) https://www.fhwa.dot.gov/policy/otps/nhcci/

65. OMB (2019) Circular no. A-94 appendix C: discount rates for costeffectiveness, lease purchase, and related analyses. Office of Management and Budget, Washington DC https://www.whitehouse.gov/omb/ information-for-agencies/circulars/

66. FHWA. 2018. "EDC-5 initiative solicitation", Every Day Counts program, 2019-2020, Federal Highway Administration Turner-Fairbank Highway Research Center, McLean, VA Private correspondence response from FHWA Director of Bridges and Structures to Chair of AASHTO T-6 Technical Committee, June 13, 2018

67. FDOT (2020) Design innovation - Fiber reinforced polymer reinforcing Transportation Innovation Challenge, Florida Department of Transportation, Tallahassee https://www.fdot.gov/structures/innovation/FRP.shtm

68. Nanni A, Rossini M, Dotelli G, Spadea S (2020) MILDGLASS: GFRP strands for resilient mild Prestressed concrete. In: NCHRP-IDEA annual progress report: new IDEAS for highway systems, vol 305. Transportation Research Board, Washington DC, pp 216-218 http://www.trb.org/Main/Blurbs/181557.aspx

69. Rossini M, Nanni A (2019) Composite strands for prestressed concrete: stateof-the-practice and experimental investigation into mild Prestressing with GFRP. Constr Build Mater 205:486-498. https://doi.org/10.1016/j. conbuildmat.2019.02.045

70. Rossini M, Nanni A (2020) MILDGLASS: GFRP Strand for resilient mild prestressed concrete. Final report for NCHRP IDEA project 207. Transportation Research Board, Washington, DC. https://trid.trb.org/view/1 709907

71. FDOT (2011) Corrosion Evaluation Report: Sheet Pile Wall State Road A1A at Flagler Beach. Florida Department of Transportation Corrosion Research Laboratory, Gainesville (Internal report, not published)

72. Islam, M. 2016. "Wall thickness evaluation protocols of the A1A Sheet Pile Retaining Wall at Flagler Beach requested by Distict-5 structures maintenance office, Jan. 8, 2016. Florida Department of Transportation internal report referenced by Denty, L., Levine. S., and Nolan, S., "low impact buried secant-pile seawall for protecting SR-A1A at Flagler Beach", National Conference on beach preservation technology, St Augustine, Feb. 7, 2018. https://www.fsbpa.com/publications/2019-tech.html

73. Nolan S, Rossini M, Nanni A (2018) Seawalls, SEACON, and sustainability in the sunshine state. In: In Proceedings of the 97th Transportation Research Board annual meeting (TRB 2018). Transportation Research Board, Washington, DC https://trid.trb.org/view/1496837

74. ACMA (2016) List of GFRP reinforced bridges in North America. American Composites Manufacturers Association, Arlington

75. Yamamoto, Y. 2018. "CFCC update", presentation at 2018 Florida transportation builders' association construction conference, Orlando FL. https://www.fdot.gov/docs/default-source/content-docs/structures/ innovation/fdot-2018-winter-frp-rc-workshop/5-FTBA-2018-Tokyo-Rope.pdf. (Accessed 31 Oct 2019).

76. Wolff R, Miesser HJ (1989) New materials for prestressing and monitoring heavy structures. Concr Int 11(9):86-89

77. Nguyen, H. T, Masuya, H., Ha, T.M., Fukada, S., Hanaoka, D., Kobayashi, K. Koida, E. 2018. "Long-term application of carbon Fiber composite cable tendon in prestressed concrete bridge-Shinmiya bridge in Japan", 3rd international conference on civil engineering and materials science, MACEX Web Conference, 206, 2018. DOl: https://doi.org/10.1051/matecconf/ 201820602011

78. Newhook JP, Bakht B, Mufti AA (2000) Design and construction of a concrete marine structure using innovative technology. In: 3rd international conference on advanced composite materials in bridges and structures. Canadian Society for Civil Engineering, Montreal, pp 777-784

79. Gooranorimi O, Nanni A (2017) GFRP reinforcement in concrete after 15 years of service. J Compos Constr 21(5):04017024

80. Benzecry, V., Brown, J., Al-Khafaji, A., Haluza, R., Koch, R., Nagarajan, M., Bakis, C., Myers, J., Nanni, A. 2019. "Durability of GFRP bars extracted from bridges with 15 to 20 years of service life", Report for ACI Strategic Development Council, June 1, 2019. https://www.acifoundation.org/Portals/12/Files/PDFs/ GFRP-Bars-Full-Report.pdf

81. Mufti, A., Onofrei, M., Benmokrane, B., Banthia, N., Boulfiza, M., Newhook, J., Bakht, B., Tadros, G., Brett P. 2005. "Durability of GFRP reinforced concrete field structures" SP-230-77: Compendium from $7^{\text {th }}$-FRPRCS, 1361-1367

82. Mufti A, Banthia N, Benmokrane B, Boulfiza M, Newhook JP (2007a) Durability of GFRP composite rods. Concr Int 29(02):37-42

83. Mufti A, Onofrei M, Benmokrane B, Banthia N, Boulfiza M, Newhook J, Bakht B, Tadros G, Brett P (2007b) Field study of glass-fibre-reinforced polymer durability in concrete. Can J Civ Eng 34(3):355-366. https://doi.org/10.1139/106-138

84. Benmokrane B, Nazair C, Loranger MA, Manalo A (2018) Field durability study of vinyl-Ester-based GFRP Rebars in concrete bridge barriers. J Bridge Eng 23(12):04018094 1-13

85. Benmokrane B, Rahman H, Mukhopadhyaya P (2000) Use of Fiber reinforced polymer reinforcement integrated with fiber optic sensors for concrete bridge deck slab construction. Can J Civ Eng 27(5):928-940

86. Aly A, Bakht B, Schaeffer J (1997) Design and construction of steel-free deck slab in Ontario. Annual Conf Can Soc Civil Eng 6:81-90

87. Tadros, G., Tromposch, E., Mufti, A. A. 1998. "Superstructure Replacement of Crowchild Trail Bridge," edited by L. Dunaszegi, Calgary, Alberta, Canada. 5th international conference on short and medium span bridges, Calgary, Alberta, Canada, 499-506

88. Tsai P, Ventura CE (1999) Waterloo creek bridge project. In: Field assessment report no. 2. University of British Columbia, Vancouver

89. Au A, Mermigas K (2018) Performance of GFRP composite slab-on-concrete girder bridge - 10 years after construction based on load tests. In: Proceedings of $10^{\text {th }}$ International Conference on Short and Medium Span Bridges. CSCE/CSGC, Quebec City

90. Lee J, Craig B, Loh P, Dimitrovski V (2010) Working towards maintenancefree bridge decks using glass fibre-reinforced polymer reinforcing bars. In: Proceedings of 8th International Conference on Short and Medium Span Bridges, vol 165, Niagara Falls. Canadian Society for Civil Engineering, Montreal, pp 1-10

91. Rossini M, Spadea S, Nanni A (2019) Pedestrian bridge as clarifying example of FRP-RC/PC design. ACI Special Publication 333-6:96-118

92. Spadea S, Rossini M, Nanni A (2018) Design analysis and experimental behavior of precast concrete double-tee girders prestressed with carbon-fiber-reinforced polymer strands. PCI J 63(1):72-84. https://doi.org/10.15554/pcij63.1-01

93. Roddenberry M, Gartman M, Nanni A, Claure G, Cadenazzi T (2020) Inspection and monitoring of fabrication and construction for the west Halls river road bridge replacement, Research project BDV30 706-01. Florida Department of Transportation, Tampa https://www.fdot.gov/structures/ innovation/hallsriverbridgeworkshop/

94. Benzecry V, Rossini M, Morales C, Nolan S, Nanni A (2021) Design of Marine dock using concrete mixed with seawater and FRP bars. J Compos Constr 25(1):05020006. https://doi.org/10.1061/(ASCE)CC.1943-5614.0001100

95. Kiani N, Rossini M, Nanni A (2020) Characterization of GFRP bars and couplers for Prestressed concrete. In: Composites and Advanced Materials Expo. CAMX virtual conference proceedings. American Composites Manufacturers Association, Orlando http://www.acmaeducationhub.org/ conference-proceedings

96. ASTM (2020) "Standard Specification for Low-Relaxation, Seven-Wire, Grade 240 [1655], Stainless Steel Strand for Prestressed Concrete", ASTM A1114 / A1114M-20. ASTM, West Conshohocken

97. FDOT (2019) Section 933 - Prestressing Strand and Bar. In: FDOT Standard Specifications for Road and Bridge Construction. Florida Department of Transportation, Tallahassee

98. Losaria J, Nolan S, Diggs A, Hartman D (2021) "US 41 over North Creek; FRP reinforced concrete two-span flat slab bridge and CFRP-Prestressed concrete/GFRP reinforced substructure and Bulkhead Wall System", SP-346-8 113-118, American Concrete Institute, Elsevier. In press

99. Younis A, Ebead U, Judd S (2018) Life cycle cost analysis of structural concrete using seawater, recycled concrete aggregate, and GFRP reinforcement. Constr Build Mater 175:152-160 
100. Younis A, Ebead U, Suraneni P, Nanni A (2020) Cost effectiveness of reinforcement alternatives for a concrete water chlorination tank. J Building Eng 27:100992

101. Cadenazzi T, Lee H, Suraneni P, Nolan S, Nanni A (2021) Evaluation of probabilistic and deterministic life-cycle cost analyses for concrete bridges exposed to chlorides. J Clean Prod (In press)

102. Pang S, Yu M, Zhu H, Yi C (2020) The corrosion probability and flexural strength of an $\mathrm{RC}$ beam under chloride ingress considering the randomness of temperature and humidity. Materials 13:2260. https://doi.org/10.3390/ ma13102260

\section{Publisher's Note}

Springer Nature remains neutral with regard to jurisdictional claims in published maps and institutional affiliations.

\section{Submit your manuscript to a SpringerOpen ${ }^{\circ}$ journal and benefit from:}

- Convenient online submission

- Rigorous peer review

- Open access: articles freely available online

High visibility within the field

- Retaining the copyright to your article

Submit your next manuscript at $\boldsymbol{\nabla}$ springeropen.com 